\title{
Peran Notaris Dalam Proses Pembuatan Akta Pendirian Perseroan Terbatas
}

\author{
Siti Fauziah Dian Novita Sari \\ Magister Kenotariatan Fakultas Hukum Universitas Islam Indonesia \\ Jln. Cik Di Tiro No. 1, Yogyakarta, 55223 \\ Diannovi452@ymail.com
}

\begin{abstract}
This study aims to examine the role of a notary in the process of drafting a Deed of Establishment of a Limited Liability Company (PT) and the authority of a public notary in providing legal counseling to the applicant. This study uses a juridical-empirical method by exploring information obtained from interviews and data from literature studies. The analytical method used is qualitative and then presented in the form of descriptive scientific work. The results concluded that the notary's role was to confirm the will of the founders, and to provide legal counsel in accordance with Law No. 40 of 2007 on Limited Liability Companies to be formulated in the Deed of Establishment of the Limited Liability Company, the notary also has the role as the attorney for founders to obtain the legal entity status from the Deed of Establishment until its announcement of the Company in the Official Gazette of the Republic of Indonesia. The responsibility of the public notary in the Deed of Establishment is only limited to the formal truth conveyed by the parties but must still refer to the provisions stipulated in Law No. 2 of 2014 on the Position of Public Notary. In exercising its authority in providing legal counseling, notaries are required to have broad insights and views in order to be able to direct the contents of the deed in accordance with the provisions of the applicable legislations. The notary is expected to apply the precautionary principle in making the Deed to minimize errors in the making.
\end{abstract}

Keywords: Deed of establishment of a limited liability company; notary; roles and obligations

\begin{abstract}
Abstrak
Penelitian ini bertujuan untuk mengkaji peran notaris dalam proses pembuatan Akta Pendirian Perseroan Terbatas (PT) dan kewenangan notaris dalam memberikan penyuluhan hukum kepada penghadap. Penelitian ini menggunakan metode yuridis-empiris dengan menggali informasi yang didapatkan dari wawancara dan data daristudi kepustakaan. Metode analisis yang digunakan adalah kualitatif untuk kemudian disajikan dalam bentuk karya ilmiah deskriptif. Hasilnya menyimpulkan bahwa notaris berperan untuk mengkonstatir kehendak para pendiri, dan memberikan penyuluhan hukum sesuai Undang-Undang No, 40 Tahun 2007 tentang Perseroan Terbatas untuk kemudian diformulasikan ke dalam Akta Pendirian Perseroan Terbatas tesebut, Notaris juga berperan sebagai kuasa dari pendiri dalam hal untuk memperoleh status badan hukum dari Akta Pendirian sampai dengan diumumkannya Perseroan tersebut di Berita Negara Republik Indonesia. Tanggung jawab Notaris dalam Akta Pendirian hanya sebatas kebenaran formal yang disampaikan oleh para pihak namun harus tetap mengacu pada ketentuan yang telah diatur dalam Undang-Undang No. 2 Tahun 2014 tentang Jabatan Notaris. Dalam menjalankan kewenangannya dalam pemberian penyuluhan hukum, notaris diharuskan memiliki wawasan dan pandangan yang luas agar dapat mengarahkan isi akta yang sesuai dengan ketentuan perundangan yang berlaku. Notaris diharapkan menerapkan prinsip kehati-hatian dalam pembuatan Akta untuk meminimalisir kesalahan dalam pembuatan Aktanya.
\end{abstract}

Kata-kata Kunci: Akta pendirian perseroan terbatas; notaris; peran dan tanggung jawab 


\section{Pendahuluan}

Kehadiran Perseroan Terbatas sebagai suatu bentuk badan usaha dalam kehidupan sehari-hari tidak lagi dapat diabaikan. Tidak berlebihan bila dikatakan bahwa kehadiran Perseroan Terbatas sebagai salah satu sarana untuk melakukan kegiatan ekonomi sudah menjadi suatu keniscayaan yang tidak dapat ditawartawar. Praktik bisnis yang dilakukan oleh para pelaku usaha, tidak lagi dipisahkan dari kehadiran Perseroan Terbatas baik dalam skala mikro, kecil, menengah, maupun besar merupakan model yang paling banyak dan paling sering dilakukan saat ini, karena adanya pembatasan tanggung jawab di dalamnya. ${ }^{1}$

Perseroan Terbatas didirikan berdasarkan perjanjian, hal ini menunjukkan sebagai suatu perkumpulan dari orang-orang yang bersepakat mendirikan sebuah badan usaha yang berbentuk perseroan terbatas. Oleh karena dasar pendiriannya menggunakan perjanjian maka pendirian Perseroan Terbatas tidak dapat dilepaskan dari syarat-syarat untuk sahnya suatu perjanjian menurut ketentuan yang ada dalam Pasal 1320 Kitab Undang-Undang Hukum Perdata. ${ }^{2}$

Unsur utama dari badan hukum adalah apa yang disebut "separate patrimony" yaitu memiliki harta sendiri yang terpisah dari pemegang saham sebagai pemilik. Karakteristik yang kedua dari badan hukum, adalah tanggung jawab terbatas dari pemegang saham sebagai pemilik perusahaan dan pengurus perusahaan. Prinsip tersebut melindungi aset perusahaan dari kreditor pemegang saham, sebaliknya tanggung jawab terbatas melindungi aset dari pemilik perusahaan yaitu pemegang perusahaan dari klaim para kreditor yang bersangkutan. Tanggung jawab terbatas artinya kreditor dalam melakukan klaim terbatas hanya kepada aset yang menjadi milik pemegang saham dan pengurus Perseroan Terbatas. Pembatasan tanggung jawab pemilik dan pengurus membedakan Perseroan Terbatas dari bentuk organisasi perusahaan lainnya yang tidak berbadan hukum. ${ }^{3}$

Perseroan terbatas sebagai badan hukum didukung dengan adanya berbagai macam peraturan perundang-undangan yang juga merupakan indikasi partisipasi

\footnotetext{
${ }^{1}$ Binoto Nadapdap, Hukum Perseroan Terbatas (Berdasarkan Undang-Undang No.40 Tabun 2007), Jala Permata Aksara, Jakarta, 2016, hlm.1.

2 Ibid., hlm. 4-5.

${ }^{3}$ Erman Rajagukguk, Butir-Butir Hukum Ekonomi, Lembaga Studi Hukum dan Ekonomi Fakultas Hukum Universitas Indonesia, Jakarta, 2011, hlm. 191.
} 
atau keterlibatan pemerintah dalam menunjang dunia perekonomian sebagai fundamen tumbuh kembangnya suatu Negara. ${ }^{4}$ Bila kita melihat kembali ketentuan peraturan mengenai Perseroan Terbatas termuat dalam Kitab UndangUndang Hukum Dagang (KUHD), definisi mengenai Perseroan Terbatas ini tidak dijumpai dalam pasal-pasalnya, namun demikian, menurut Sutantya dan Sumatoro dari Pasal 36, 40, 42, dan Pasal 45 KUHD dapat disimpulkan bahwa suatu Perseroan Terbatas mempunyai unsur-unsur sebagai berikut: ${ }^{5}$

1. Adanya kekayaan terpisah dari kekayaan pribadi masing-masing pesero (pemegang saham) dengan tujuan untuk membentuk sejumlah dana sebagai jaminan bagi semua perikatan perseroan;

2. Adanya pesero atau pemegang saham yang tanggung jawabnya terbatas pada jumlah nominal saham yang dimilikinya. Sedangkan mereka semua di depan rapat umum pemegang saham (RUPS), merupakan kekuasaan tertinggi dalam organisasi perseroan, yang berwenang mengangkat dan memberhentikan direksi dan komisaris, berhak menetapkan garis-garis besar kebijaksanaan menjalankan perusahaan dan menetapkan hal-hal yang belum ditetapkan dalam anggaran dasar dan lain-lain;

3. Adanya pengurus (direksi), dan pengawas (komisaris) yang merupakan satu kesatuan pengurusan dan pengawasan terhadap perseroan dan tanggung jawabnya terbatas pada tugasnya, yang harus sesuai dengan anggaran dasar atau keputusan RUPS.

Ketentuan mengenai pendirian Perseroan Terbatas dalam Pasal 7 ayat (1) UUPT harus didirikan oleh paling sedikit 2 orang, di mana suatu Perseroan Terbatas berdiri dan/atau semata-mata karena perjanjian oleh dua orang atau lebih dengan akta resmi atau akta notaris. Jika ditinjau dari segi hukum perjanjian, pendirian Perseroan sebagai badan hukum, bersifat "kontraktual" (contractual, by contract") yakni berdirinya perseroan merupakan akibat yang lahir dari perjanjian. Selain bersifat kontraktual, juga bersifat "konsensual" berupa adanya kesepakatan untuk mengikat perjanjian mendirikan perseroan. ${ }^{6}$

Dalam pendirian Perseroan Terbatas tersebut jika didirikan oleh suami istri tanpa melakukan perjanjian perkawinan (pemisahan harta) terlebih dahulu tetap

${ }^{4}$ Devie Lambe, "Peran dan Tanggung Jawab Notaris dihubungkan dengan Kinerja Sistem Administrasi Badan Hukum (SABH) dalam Pendirian PT”, Tesis, Universitas Indonesia, Jakarta, 2011, hlm.1.

${ }_{5}^{5}$ Agus Budiarto, Kedudukan Hukum dan Tanggung Jawab Pendiri Perseroan Terbatas, Ghalia Indonesia, Jakarta, 2002, hlm. 24.

${ }^{6}$ M. Yahya harahap, Hukum Perseroan Terbatas cet.6, Sinar Grafika, Jakarta, 2016, hlm. 35. 
tidak memenuhi unsur pendirian perseroan yang sah seperti dalam ketentuan Pasal 7 ayat (1) UUPT yang menyatakan bahwa perseroan didirikan oleh 2 orang atau lebih.

Menurut Buku Satu Kitab Undang-undang Hukum Perdata Pasal 26 yaitu, perkawinan hanyalah dipandang sebagai hubungan perdata belaka, dan dalam Pasal 119 yang secara eksplisit menerangkan bahwa kepemilikan harta suami dan istri adalah satu, yang bunyinya sebagai berikut :7

"mulai saat perkawinan dilangsungkan, demi hukum berlakulah persatuan bulat antara harta kekayaan suami dan istri, sekedar mengenai itu dengan perjanjian kawin tidak diadakan ketentuan lain. Persatuan itu sepanjang perkawinan tak boleh diadakan atau diubah dengan sesuatu persetujuan antara suami dan istri."

Berarti apabila antara suami istri ada percampuran kekayaan, maka sesungguhnya suami juga terikat dengan perjanjian-perjanjian yang diadakan oleh istrinya tersebut, atau sebaliknya. Dalam konsepsi hukum perkawinan yang mengatur harta persatuan antara suami dan istri di dalam pasal tersebut, hanya dapat dikesampingkan dengan mengadakan suatu perjanjian kawin, sebagaimana diatur dalam Pasal 139 sampai dengan Pasal 167 KUHPerdata.

Dalam menjalankan tugas dan kewenangannya sebagai pejabat umum, Notaris selain mengkonstantir kehendak para pihak yang akan dituangkan dalam bentuk Akta Pendirian Perseroan Terbatas juga memiliki kewenangan untuk memberikan penyuluhan hukum terkait dengan pembuatan akta pendirian. Hal ini telah ditegaskan di dalam ketentuan Pasal 15 ayat (2) huruf e UUJN yang menyatakan bahwa Notaris berwenang pula memberikan penyuluhan hukum sehubungan dengan pembuatan akta.

\section{Rumusan Masalah}

Berdasarkan pendahuluan di atas maka rumusan masalah pada penelitian ini adalah sebagai berikut: pertama, apa peran Notaris dalam proses pembuatan akta pendirian Perseroan Terbatas yang menjadi kewenangannya dalam memberikan penyuluhan hukum kepada para penghadap? Kedua, bagaimana tanggung jawab

${ }^{7}$ R. Subekti \& R Tjitrosudibio, Kitab Undang-Undang Hukum Perdata, cetakan ketigapuluh Sembilan, Pradnya Paramita, Jakarta, 2008, hlm. 29. 
Notaris jika dalam pembuatan akta pendirian Perseroan Terbatas, Notaris tidak memperhatikan kepentingan para pihak?

\section{Tujuan Penelitian}

Adapun tujuan dari penelitian ini adalah untuk: pertama, menganalisis peran Notaris dalam proses pembuatan akta pendirian Perseroan Terbatas serta kewenangan Notaris dalam memberikan penyuluhan hukum kepada penghadap dalam rangka pembuatan akta pendirian Perseroan Terbatas; dan kedua, mengkaji lebih mendalam tentang tanggung jawab Notaris apabila dalam pembuatan akta pendirian Perseroan Terbatas tidak memperhatikan kepentingan para pihak yang terkait di dalamnya.

\section{Metode Penelitian}

Obyek penelitian dalam penulisan tesis ini adalah Pasal 15 dan Pasal 16 terkait Kewenangan dan Kewajiban Notaris berdasarkan Undang-Undang Nomor 2 Tahun 2014 tentang Jabatan Notaris. Sedangkan subjek penelitian yang akan diteliti oleh penulis dalam tesis ini adalah para Notaris yang sudah berpraktik lebih dari 5 tahun yang juga sebagai akademisi. Data penelitian diperoleh dari hasil wawancara dari para narasumber yaitu para Notaris yang sudah berpraktik selama lebih dari 5 tahun; dan yang juga berprofesi sebagai akademisi.

Penelitian ini dilakukan secara yuridis-empiris, disebut pula dengan penelitian lapangan. Penelitian ini bertitik tolak dari data primer, yakni data yang diperoleh langsung dari masyarakat sebagai sumber pertama dengan melalui penelitian lapangan, yang dilakukan baik melalui pengamatan (observasi), wawancara, ataupun penyebaran kuesioner. ${ }^{8}$ Di mana penulis mendapatkan data primer dengan melakukan wawancara kepada Notaris Kota Yogyakarta yang telah berpraktik lebih dari 5 tahun dan juga sebagai akademisi, dan dipadukan dengan data sekunder yang didapatkan melalui studi kepustakaan.

${ }^{8}$ Joenaedi Efendi, Metode Penelitian Hukum: Normatif dan Empiris, Prenadamedia Group, Depok, 2016, hlm. 148. 
Penelitian ini menggunakan pendekatan perundang-undangan (Statute Aprroach), dalam metode ini peneliti meneliti tentang aturan tertulis yang memuat norma hukum yang mengikat secara umum dan dibentuk atau ditetapkan oleh lembaga negara atau pejabat yang berwenang melalui prosedur yang ditetapkan dalam peraturan perundang-undangan berupa legislasi dan regulasi. ${ }^{9}$ Peraturan perundang-undangan yang digunakan dalam penelitian ini di antaranya adalah Undang-undang Nomor 2 Tahun 2014 tentang Jabatan Notaris khususnya lebih mengacu kepada Kewenangan dan Kewajiban Notaris yang terdapat dalam Pasal 15 dan Pasal 16. Serta Undang-Undang Nomor 40 Tahun 2007 tentang Perseroan Terbatas.

\section{Hasil Penelitian dan Pembahasan}

\section{Peran Notaris dalam Proses Pembuatan Akta Pendirian Perseroan Terbatas dan Kewenangannya dalam Memberikan Penyuluhan Hukum}

Notaris oleh undang-undang diberi kewenangan untuk menuangkan semua perbuatan, perjanjian dan penetapan yang dikehendaki oleh pihak-pihak guna mengkonstantirkannya ke dalam sebuah Akta Autentik dan agar Akta yang dibuatnya itu memiliki kekuatan bukti yang lengkap dan memiliki keabsahan di mana dalam hal ini Akta yang dimaksudkan adalah Akta Pendirian PT. Notaris dituntut pula memenuhi semua ketentuan-ketentuan jabatan Notaris dan peraturan-peraturan lainnya yang terkait dalam Akta Pendirian PT. Notaris dalam hal ini adalah sebagai pengkaji apakah kehendak para pihak tersebut tidak bertentangan dengan peraturan perundang-undangan yang berlaku, Notaris dalam melaksanakan jabatanya juga harus berpijak kepada Undang-undang Jabatan Notaris (untuk selanjutnya disebut UUJN). Hal tersebut dilakukan oleh Notaris sebagai bentuk kewajiban untuk menyampaikan syarat-syarat autentisitas, keabsahan dan sebab-sebab kebatalan suatu akta, juga sebagai sikap preventif adanya cacat hukum Akta Notaris yang dapat mengakibatkan hilangnya autentisitas dan batalnya Akta Notaris, yang dapat menimbulkan kerugian kepada masyarakat, terutama pihak-pihak yang berkepentingan. ${ }^{10}$

\footnotetext{
${ }^{9}$ Peter Mahmud Marzuki, Penelitian Hukum, Kencana, Jakarta, 2005, hlm. 137. 2011, hlm. 71

${ }_{10}$ Sjaifurrachman, Aspek Pertanggungjawaban Notaris dalam Pembuatan Akta Cet.1, Mandar Maju, Bandung,
} 
Notaris juga berperan pula untuk melakukan pesan nama PT dan sebagai kuasa dari pendiri dalam hal untuk memperoleh status badan hukum dari Akta Pendirian PT tersebut sampai dengan diumumkannya Perseroan tersebut di Berita Negara Republik Indonesia. ${ }^{11}$ Hal tersebut diperkuat dengan adanya dasar hukum yaitu berdasarkan pada Pasal 2 ayat (1) PERMEN No. M. 01-HT 01-10/2007 Tentang Tata Cara Pengajuan Permohonan Badan Hukum dan Persetujuan Perubahan Anggaran Dasar, Penyampaian Pemberitahuan Anggaran Dasar dan Perubahan Anggaran Dasar dan Perubahan Data Perseroan (untuk selanjutnya disebut PERMEN No. M. 01-HT 01-10/2007), bahwa yang memiliki hak untuk mengajukan permohonan pendiri memberi kuasa kepada Notaris sehingga yang sah secara formil mengajukan permohonan adalah Notaris "dalam kualitas dan kapasitas sebagai kuasa" dari pendiri. Pasal 2 ayat (1) Permen tersebut berbunyi "pengajuan permohonan pengesahan badan hukum Perseroan dilakukan oleh Notaris sebagai kuasa dari pendiri". ${ }^{12}$

Notaris dalam penyuluhan hukum kepada para pendiri PT untuk memberikan gambaran bahwa PT merupakan badan usaha yang berbadan hukum yang ada di Indonesia, lain halnya dengan badan usaha lainnya seperti CV maupun Firma yang tidak berbadan hukum. Notaris menjelaskan juga mengenai perbandingan antara perseroan yang berbadan hukum dan bukan berbadan hukum terkait dengan tanggung jawabnya. Notaris menjelaskan bagaimana pandangan pihak ketiga memandang PT yaitu yang bertanggung jawabnya adalah modal bukan person, Notaris juga menjelaskan mengenai tentang peraturanperaturan lainnya terkait PT yang sudah diatur secara jelas dalam Undangundang. 13

Dalam pemberian penyuluhan hukum terkait dengan maksud dan tujuan yang hendak didirikan oleh para pendiri harus sesuai dengan klasifikasi bidang usaha yang terdapat dalam suatu PT harus sesuai dengan Peraturan Kepala Badan

\footnotetext{
11 Wawancara dengan Notaris Mustofa, S.H, Pada Tanggal 1 November 2018, Pukul 15.00 (untuk selanjutnya disebut Narasumber II)

12 Yahya Harahap., Op. Cit., hlm. 175.

13 Wawancara dengan Notaris Bimo Seno Sanjaya, S.H, Pada Tanggal 26 November 2018, pukul 13.20 (untuk selanjutnya disebut Narasumber III)
} 
Pusat Statistik Nomor 19 Tahun 2007 tentang perubahan atas Peraturan Kepala Badan Pusat Statistik Nomor 95 Tahun 2015 tentang Klasifikasi Baku Lapangan Usaha Indonesia (untuk selanjutnya disingkat KLBI) untuk kemudian dijabarkan dalam Akta Pendirian PT oleh Notaris dan disesuai dengan kehendak pendiri, kemudian dilakukan pesan nama bagi PT, cetak SK Pengesahan dari Direktorat Jendral Administrasi Hukum Umum (AHU) Kementerian Hukum dan Hak Asasi Manusia. Setelah mendapatkan Surat Keputusan tersebut para pendiri mendaftarkannya ke dalam sistem Online Single Submission (selanjutnya disingkat OSS), karena OSS bukanlah kewajiban dari Notaris. ${ }^{14}$

Sesuai dengan Pasal 7 ayat (4) bahwa perseroan mendapat status badan hukum pada tanggal diterbitkannya Keputusan Menteri Hukum dan Hak Asasi Manusia mengenai pengesahan badan hukum Perseroan, dengan mengajukan permohonan melalui jasa teknologi informasi sistem administrasi badan hukum secara elektronik kepada Menteri paling lambat 60 hari terhitung sejak tanggal Akta Pendirian ditandatangani dengan mengisi format isian yang diatur di dalam Pasal 9 ayat (1) UUPT, sekurang-kurangnya harus memuat: 15

a. "Nama dan tempat kedudukan Perseroan;

b. Jangka waktu berdirinya Perseroan;

c. Maksud dan tujuan serta kegiatan usaha Perseroan;

d. Jumlah modal dasar, modal ditempatkan, dan modal disetor;

e. Alamat lengkap Perseroan."

Payung hukum terkait OSS sendiri berupa Peraturan Pemerintah No. 24 Tahun 2018 Tentang Pelayanan Perizinan Berusaha Terintegrasi Secara Elektronik (untuk selanjutnya disebut PP No. 24/2018), dalam PP No. 24/2018 terdapat 20 sektor usaha antara lain sektor ketenagalistrikan, pertanian, keuangan, pariwisata, pendidikan dan kebudayaan hingga pengoperasian dan usaha mikro kecil, menengah serta ketenaganukliran. Pendaftaran dalam sistem OSS ini dilakukan dengan memasukkan Nomor Induk Kependudukan (NIK), nomor pengesahan Akta Pendirian atau nomor pendaftaran PT untuk selanjutnya lembaga OSS menerbitkan Nomor Induk Berusaha (NIB) yang berbentuk 13 (tigabelas) digit

\footnotetext{
14 Wawancara dengan Notaris Ramdhan Dompas, S.H., M.Kn, Pada Tanggal 14 Desember 2018, pukul 15.45

${ }^{15}$ Yahya Harahap, Op. Cit., hlm.175.
} 
angka acak yang dimaksudkan untuk mendapatkan izin usaha dan izin komersial atau operasional yang juga berlaku sebagai Tanda Daftar Perusahaan dan setelah pendiri melakukan pendaftaran melalui pengisian data secara lengkap dan mendapatkan Nomor Pokok Wajib Pajak (NPWP). ${ }^{16}$

Setelah perseroan disahkan sebagai badan hukum, maka perseroan tersebut harus memenuhi asas publisitas, yaitu dengan mendaftarkan perseroannya ke dalam daftar perseroan yang diterbitkan dan diselenggarakan oleh Menteri di mana hal tersebut juga telah diatur dalam UUPT, yang secara eksplisit berkaitan dengan Undang-Undang Nomor 3 Tahun 1982 dan Keputusan Menteri Perindustrian dan Perdagangan Republik Indonesia Nomor 12/MPP/Keo/1988 Tentang penyelenggaraan wajib daftar perusahaan. Dengan mensyaratkan setiap korporasi wajib mendaftarkan korporasinya berdasarkan akta-akta yang telah diotorisasi oleh Menteri Hukum dan Hak Asasi Manusia yang meliputi Akta Pendirian sesuai dengan pengesahan menteri kehakiman. ${ }^{17}$

Dalam hal suami istri yang belum melakukan perjanjian pemisahan harta hendak mendirikan sebuah PT, maka Notaris tidak berkenan untuk membuatkan Akta tersebut karena dianggap tidak memenuhi syarat pendirian PT. oleh karena itu Notaris dapat memberikan saran untuk melibatkan Pihak Ketiga untuk turut serta dalam pendiriannya. Bila sudah melibatkan pihak ketiga Notaris berpendapat pula suami istri tersebut berhak mengambil bagian saham yang sama dalam PT tersebut, karena Notaris berpendapat bahwa yang disetorkan hanya sejumlah uang sebagai modal dasar PT, dan istri dianggap cakap untuk melakukan perbuatan hukum terkait dengan harta benda bergerak meskipun dalam harta suami istri itu tidak dilakukan pemisahan harta. ${ }^{18}$

Menurut Penulis jika dalam hal suami istri yang tidak mengadakan perjanjian perkawinan pemisahan harta tidak dapat mendirikan sebuah PT sehingga suami

${ }^{16}$ Humas Sekretariat Kabinet Republik Indonesia, PP No. 24/2018 tentang Pelayanan Perizinan Berusaha Terintegrasi Secara Elektronik, http://setkab.go.id/inilah-pp-no-242018-tentang-pelayanan-perizinan-berusahaterintegrasi-secara-elektronik/, diakses pada tanggal 14 Desember 2018, pukul 10.33. $27-28$.

${ }^{17}$ Freddy Harris dan Teddy Anggoro, Hukum Perseroan Terbatas, cet.1, Ghalia Indonesia, Bogor, 2010, hlm.

18 Wawancara Narasumber II 
dan istri tetaplah terhitung subjek jika hendak melakukan suatu perbuatan hukum baik perikatan maupun lainnya. Persatuan harta kekayaan suami istri baik harta kekayaan yang bergerak dan yang tidak bergerak, baik yang saat ini maupun yang akan datang hal tersebut dikarenakan menurut KUHPerdata Bagian Kesatu tentang persatuan harta kekayaan menurut undang-undang Pasal 119 yang menyebutkan bahwa :19

"mulai saat perkawinan dilangsungkan, demi hukum berlakulah persatuan bulat antara harta kekayaan suami dan istri, sekedar mengenai itu dengan perjanjian kawin tidak diadakan ketentuan lain. Persatuan itu sepanjang perkawinan tak boleh diadakan atau diubah dengan sesuatu persetujuan antara suami dan istri."

Dengan dilangsungkannya suatu perkawinan akibat hukum yang timbul terhadap kedudukan istri dalam pengurusan harta perkawinan dan dalam melakukan tindakan hukum baik terkait harta pribadinya maupun harta kekayaan dalam perkawinan. Menurut Hukum Perdata barat atau dikenal dengan KUHPerdata apabila seorang wanita yang terikat perkawinan dengan seorang pria, maka istri tersebut menjadi tidak lagi mempunyai kecakapan dalam bertindak (handelings onbekwaam). ${ }^{20}$ Menurut J. Satrio yang dikutip dari buku Rosnidar Sembiring, Hukum harta perkawinan adalah peraturan yang mengatur akibatakibat perkawinan terhadap harta kekayaan suami-istri yang telah melangsungkan perkawinan. ${ }^{21}$

Notaris diberikan wewenang untuk menuangkan segala perbuatan, perjanjian dan penetapan yang dikehendaki oleh pihak-pihak yang datang kepadanya untuk mengkonstantirkannya dan dituangkan ke dalam sebuah Akta Autentik, dengan tujuan agar akta tersebut memilik kekuatan bukti yang lengkap dan memiliki keabsahan. Oleh karena itu Notaris wajib memenuhi segala ketentuan jabatannya dan peraturan-peraturan lainnya. Notaris juga berperan untuk mengkaji apakah suatu yang dikehendaki oleh penghadap untuk dituangkan ke dalam Akta tersebut tidak bertentangan dengan peraturan

\footnotetext{
${ }^{19}$ Kitab Undang-Undang Hukum Perdata

${ }^{20}$ J. Andy Hartanto, Hukum Harta Kekayaan Perkawinan Menurut "Burgelijk Wetboek" dan undang-Undang Perkawinan cet.2, Laksbang Grafika, Yogyakarta, 2012, hlm. 7.

21 Rosnidar Sembiring, Hukum Keluarga Harta-harta benda dalam Perkawinan, PT. Raja grafindo Persada, Jakarta, 2016, hlm. 85.
} 
perundang-undangan yang berlaku. Notaris berkewajiban untuk mengetahui dan memahami syarat-syarat autentisitas, keabsahan dan sebab-sebab kebatalan suatu akta, hal tersebut sangatlah penting untuk menghindari secara preventif adanya cacat hukum Akta Notaris yang dapat mengakibatkan batalnya Akta dan menimbulkan kerugian kepada pihak-pihak yang berkepentingan. ${ }^{22}$

Pada dasarnya hukum dapat memberikan beban tanggung gugat atau tanggung jawab atas tindakan yang dilakukan oleh Notaris, namun hal tersebut tidak berarti segala kerugian terhadap pihak ketiga seluruhnya menjadi tanggung gugat dan tanggung jawab Notaris. Hukum telah memberi batasan atau rambu tanggung gugat dan tanggung jawab Notaris, sehingga tidak semua kerugian pihak ketiga merupakan tanggung gugat dan tanggung jawab Notaris. Hal tersebut yang dikenal dengan bentuk perlindungan hukum terhadap Notaris sebagai pejabat umum yang bertugas memberikan pelayanan. Secara normatif, peran Notaris hanyalah untuk mengkonstantir kehendak para pihak untuk kemudian dituangkan dalam sebuah Akta Autentik, sehingga hak dan kewajiban hukum yang dilahirkan dari perbuatan hukum yang disebut dalam Akta tersebut hanya mengikat pihak-pihak dalam akta itu, apabila terjadi sengketa mengenai isi perjanjian maka Notaris tidak terlibat dalam pelaksanaan kewajiban dan dalam penuntutan suatu hak. ${ }^{23}$ Tanggung jawab Notaris yang berkaitan dengan keautentikan Akta pendirian PT hanyalah sebatas dengan kebenaran formal dan bukan materil, yang telah ditentukan dalam peraturan perundang-undangan khususnya UUPT, bahwa yang perlu diutarakan oleh para pendiri untuk dituangkan ke dalam Akta pendirian berupa anggaran dasar yang telah diatur dalam Pasal 15 UUPT, di antaranya: 24
a. "Nama dan tempat kedudukan perseroan;
b. Maksud dan tujuan serta kegiatan usaha perseroan yang sesuai dengan peraturan perundang-undangan yang berlaku;
c. Jangka waktu berdirinya perseroan;
d. Besarnya jumlah modal dasar, modal ditempatkan dan modal disetor;

\footnotetext{
22 Sjaifurachman, Op. Cit., hlm. 121

${ }^{23}$ Ibid., hlm. 192

${ }^{24}$ Undang-Undang Nomor 40 Tahun 2007 tentang Perseroan Terbatas.
} 
e. Jumlah saham, jumlah kualifiasi saham apabila ada, berikut jumlah saham untuk tiap klasifikasi, hak-hak yang melekat pada setiap saham, dan nilai nominal setiap saham;

f. Nama jabatan dan jumlah anggota Direksi dan Dewan Komisaris;

g. Penetapan tempat dan tata cara penyelenggaraan RUPS;

h. Tata cara pengangkatan, penggantian, pemberhentian anggota Direksi dan Dewan Komisaris;

i. Tata cara penggunaan laba dan pembagian dividen."

Dalam menjalankan jabatannya apabila Notaris melakukan pelanggaran berdasarkan ketentuan yang telah diatur dalam UUJN, maka Notaris harus bertanggungjawab dengan cara dikenakan sanksi atau dijatuhi sanksi berupa sanksi perdata, sanksi administrasi, sanksi pidana, kode etik jabatan Notaris atau kombinasi sanksi. Dengan demikian Notaris harus bertanggungjawab terhadap Akta yang telah dibuatnya. ${ }^{25}$

Dalam Pasal 84 UUJN ditentukan ada 2 jenis sanksi perdata, jika Notaris melakukan tindakan pelanggaran terhadap pasal tertentu, di antaranya:

1. Akta Notaris yang mempunyai kekuatan pembuktian sebagai akta di bawah tangan

2. Akta notaris menjadi batal demi hukum.

Pada prinsipnya Notaris tidak diperkenankan untuk membuat Akta pendirian PT di mana para pendirinya hanya terdiri dari suami dan istri yang tidak melakukan perjanjian perkawinan pemisahan harta karena antara harta suami dan istri bersifat satu, oleh karena hal tersebut pembuatan aktanya tetap tidak memenuhi syarat formil yang telah ditetapkan dalam Pasal 7 ayat (1) UUPT di mana "pendirian sebuah PT didirikan minimal 2 (dua) orang".

Karena pada dasarnya Akta Notaris sendiri bersifat sebagai alat bukti yang mempunyai kekuatan pembuktian yang sempurna dengan syarat bahwa persyaratan materil (substantif) dan formil (prosedural) pembuatan aktanya terpenuhi dan tidak adanya kesalahan prosedur. ${ }^{26}$ Apabila Akta pendirian PT yang dibuat oleh Notaris tersebut tidak memenuhi syarat formil yang telah diatur dalam Pasal 7 ayat (1) UUPT, oleh karenanya akta tersebut dapat diajukan kepada 
pengadilan dan apabila terbukti bahwa akta tersebut tidak memenuhi syarat formil pendirian sebuah PT, maka pengadilan dapat menyatakan Akta Autentik tersebut sebagai akta yang mempunyai kekuatan pembuktian akta yang di bawah tangan. Apabila kadar pembuktian terhadap Akta pendirian PT tersebut terdegradasi menjadi akta di bawah tangan, maka sifat tanggung jawab terbatas sebuah PT sebagai perseroan berbadan hukum berubah menjadi perseroan yang tidak berbadan hukum. Hal tersebut mengakibatkan tanggung jawab yang terbatas menjadi tanggung jawab tidak terbatas bagi para persero-nya.

Berdasarkan hasil wawancara dengan Narasumber III, apabila seorang Notaris tetap membuatkan Akta Pendirian PT di mana di dalamnya pendiri tersebut hanya suami istri tanpa adanya perjanjian pemisahan harta maka, menurut Narasumber Notaris tidak dapat diberikan sanksi baik administratif, perdata, maupun pidana. Karena yang diatur di dalam UUJN hanya sebatas mengenai sanksi administratif berupa teguran ataupun pemberhentian dari MPD hanya sebatas pada perbuatan yang melanggar larangan-larangan yang ada dalam UUJN. Melainkan yang dapat terkena dampak atas Akta pendirian PT tersebut hanya sebatas pada Aktanya saja, karena kedudukan Akta pendirian PT tersebut menjadi tidak sah sehingga menyebabkan PT yang berbadan hukum tersebut menjadi tidak berbadan hukum sehingga tanggung jawabnya menjadi tidak terbatas. ${ }^{27}$

Berdasarkan Pasal 1869 KUHPerdata suatu akta Notaris dapat dikategorikan menjadi akta di bawah tangan apabila akta tersebut dibuat oleh pejabat umum yang tidak berwenang yang bersangkutan membuatnya atau tidak mampunya pejabat umum yang bersangkutan dan adanya cacat dalam bentuk dalam akta tersebut. Notaris yang membuat Akta pendirian PT yang di dalamnya hanya terdapat suami dan istri tanpa adanya perjanjian perkawinan pemisahan harta, menurut penulis telah mengesampingkan ketentuan dalam Pasal 16 ayat (1) huruf a di mana Notaris tersebut "memihak" dalam hal adalah ini para pendiri PT, serta tanpa memperhatikan akibat kerugian bagi pihak ketiga yang berkaitan secara

27 Wawancara dengan Narasuber III 
langsung maupun tidak langsung dengan kegiatan PT tersebut yang dikemudian hari akan timbul kerugian bagi segala pihak, hal tersebut mengakibatkan Akta tersebut menjadi di bawah tangan dikarenakan cacatnya suatu Akta dan mengakibatkan Akta Autentik tersebut terdegradasi menjadi Akta di bawah tangan.

Tanggung Jawab Notaris dalam Hal Pembuatan Akta Pendirian Perseroan Terbatas

Dengan demikian tanggung jawab yang dapat dibebankan dalam pembuatan Akta pendirian PT yang di dalamnya suami istri yang belum mengadakan perjanjian pemisahan harta sebelumnya hanyalah mengakibatkan hukum Akta Notaris dalam hal ini Akta pendirian PT tersebut terdegradasi kekuatan pembuktiannya menjadi Akta di bawah tangan, maka terhadap Akta Autentik tersebut dianggap tidak pernah ada dan tidak pernah dibuat serta tidak dapat dijadikan dasar suatu tuntutan dalam bentuk penggantian biaya, ganti rugi dan bunga. Sehingga kedudukannya sebagai perseroan berbadan hukum berbuah menjadi perseroan yang bukan berbadan hukum dan tanggung jawab yang terbatas dalam PT turut pula berubah menjadi tanggung jawab tidak terbatas bagi pendirinya.

\section{Penutup}

Dalam pembuatan Akta Pendirian Perseroan Terbatas (untuk selanjutnya disebut PT) Notaris berperan meresmikan atau verleden Akta serta memberikan penyuluhan hukum kepada para pendiri perseroan. Notaris juga berperan untuk melakukan pesan nama PT dan sebagai kuasa dari pendiri dalam hal untuk memperoleh status badan hukum dari Akta Pendirian PT tersebut sampai dengan diumumkannya Perseroan tersebut di Berita Negara Republik Indonesia.

Notaris bertanggungjawab dalam memformulasikan Akta Pendirian PT dengan mengacu pada kebenaran formal yang disampaikan oleh para pendiri perseroan kepada Notaris, dan dalam memformulasikan Akta, Notaris harus mengacu pada ketentuan kewajiban yang telah diatur dalam Pasal 16 ayat (1) huruf a Undang-Undang Jabatan Notaris untuk tidak memihak agar produk sebuah Akta tersebut tidak terdegradasi. 
Oleh sebab itu, Notaris dalam menjalankan jabatan dan kewenangannya berupa pemberian penyuluhan hukum kepada para penghadap diharuskan mempunyai wawasan dan pandangan yang luas terkait dengan akta yang dibuatnya. Karena selain mengkonstantir kehendak para pihak Notaris juga dapat mengarahkan isi akta agar sesuai dengan peraturan perundang-undangan yang berlaku. Notaris dalam menjalankan tugas dan jabatannya diharapkan lebih bersikap hati-hati dalam segala pembuatan Akta Autentik dalam hal ini pembuatan Akta pendirian PT, Untuk meminimalisir hal yang tidak diinginkan kemudian hari yang mengakibatkan kerugian kepada pihak terkait karena pada dasarnya Akta Notaril sebagai alat bukti yang terkuat dan terpenuh serta bersifat preventif.

\section{Daftar Pustaka}

\section{Buku}

Budiarto, Agus, Kedudukan Hukum dan Tanggung Jawab Pendiri Perseroan Terbatas, Ghalia Indonesia, Jakarta, 2002.

Efendi, Joenaedi, Metode Penelitian Hukum: Normatif dan Empiris, Prenadamedia Group, Depok, 2016.

Harahap, M. Yahya, Hukum Perseroan Terbatas cet.6, Sinar Grafika, Jakarta, 2016.

Harris, Freddy \& Teddy Anggoro, Hukum Perseroan Terbatas, cet.1 Ghalia Indonesia, Bogor, 2010.

Hartanto, J. Andy, Hukum Harta Kekayaan Perkawinan Menurut "Burgelijk Wetboek" dan undang-Undang Perkawinan cet. 2, Laksbang Grafika, Yogyakarta, 2012.

Marzuki, Peter Mahmud, Penelitian Hukum, Kencana, Jakarta, 2005.

Nadapdap, Binoto, Hukum Perseroan Terbatas (Berdasarkan Undang-Undang No.40 Tahun 2007), Permata Aksara, Jakarta, 2016.

Rajagukguk, Erman, Butir-Butir Hukum Ekonomi, Lembaga Studi Hukum dan Ekonomi Fakultas Hukum Universitas Indonesia, Jakarta, 2011.

Sembiring, Rosnidar, Hukum Keluarga Harta-harta benda dalam Perkawinan, PT.Raja grafindo Persada, Jakarta, 2016.

Subekti, R. \& R Tjitrosudibio, Kitab Undang-Undang Hukum Perdata cetakan ketigapuluh Sembilan, Pradnya Paramita, Jakarta, 2008.

Sjaifurrachman, Aspek Pertanggungjawaban Notaris dalam Pembuatan Akta Cet.1, Mandar Maju, Bandung, 2011. 
Syamsudin, M., Operasionalisasi Penulisan Hukum, PT. RajaGrafindo Persada, Jakarta, 2007.

\section{Tugas Akhir}

Lambe, Devie, "Peran dan Tanggung Jawab Notaris dihubungkan dengan Kinerja Sistem Administrasi Badan Hukum (SABH) dalam Pendirian PT", Tesis, Universitas Indonesia, Jakarta, 2011.

\section{Internet}

"Peraturan Pemerintah No. 24/2018 tentang Pelayanan Perizinan Berusaha Terintegrasi Secara Elektronik", http:/ / setkab.go.id/inilah-pp-no-242018tentang-pelayanan-perizinan-berusaha-terintegrasi-secara-elektronik/, diakses tanggal 14 Desember 2018. 